\title{
Transnational crime and trafficking in persons: Quantifying the nature, extent and facilitation of a growing phenomenon
}

For as long as there have been people there has been migration. People have always sought to improve their lot. Many people have done so willingly whilst others have believed there to be little option for them but to relocate in order to avoid violence, terror or economic dysfunction. It is said that for those living in Somalia, Egypt looks pretty good. For those living in Egypt, Greece looks pretty good. For those living in Greece, Belgium looks pretty good and for those living in Belgium, Canada looks pretty good. The process of globalisation has facilitated, increased and sustained the significant movement of populations. Although this thought process is not universal it is clear that for some the grass will always be greener elsewhere. This fact constitutes a significant political challenge for most countries which are required both to ensure sufficient immigration to provide succour to the national economy but also to ensure that sovereignty is maintained over such movement. The IOM (2005) has argued, for example, that Central Asia, whilst not a recognised trafficking 'hot spot', is seeing huge irregular flows of people within the region and out of it. It notes (IOM 2005) that ' $[\mathrm{t}] \mathrm{he}$ limited access to transparent and efficient visa and recruitment services means that the majority of these movements are irregular, and a proportion involve trafficking. Both the scale of movements and the limited capacity in the region to assist and manage migration heightens potentials for exploitation'. It is important to note, however, that this paper concentrates upon trafficking of persons rather than smuggling of persons. In the case of the former a person may be forced to relocate and/or be recruited to work overseas but misled as to the nature of (the usually exploitative) work they initially undertook to perform. In the case of the latter a person pays simply to be relocated to another country, is fully complicit in the process and is rarely, if ever, exploited by those who facilitated his/her relocation once s/he is in situ.

Transnational crime, like nature, abhors a vacuum. Given the ingenuity of such criminals in creating new crime targets and methods or of enhancing the impact they might have on pre-existing crime types, it should come as little surprise that transnational criminals should involve themselves in trafficking. The UNODC (2003) notes that ' $[t]$ here is significant evidence of organised crime involvement in the [human trafficking], in particular in the ownership of the means of exploitation, particularly in a) regional hubs for the demanding industries, and b) more distant but lucrative destination markets.' The UNODC (2003) notes that ' $[t]$ he flows of trafficked victims throughout the [East Asia and Pacific] region are numerous and complex. There is not one phenomenon at work in this region, there are many human trafficking typologies - with different causes, different locations, different levels of organised crime involvement, different degrees of consent and complicity, and of course with different sources and destinations.' The report maintains that in Thailand in particular, '[t]he extent of the organised crime involvement in the Thai sex 
industry contributes to Thailand being a major facilitation centre (featuring housing, banking, entertainment, concealment of activity, protection) for organised crime groups running trafficking networks across the region and globally' (UNODC 2003).

The opportunities for criminal entrepreneurs to become involved in trafficking of persons have been created by lacuna that exists between the cumulative effect of this increased desire for people to leave their homelands on the one hand and the desire of nation states to protect their borders and to bolster the immigration policies designed to assist with that protection on the other.

The strength of traffickers is assisted by the difficulties and sometimes inadequacies of the law enforcement and criminal justice responses to the trafficking phenomenon. Piotrowicz (2004), for example, notes that securing convictions against traffickers can be problematic. Reasons for this include the fact that trafficked women may be considered to have breached the immigration and/or employment laws of the destination country. Despite changes in the political and social climate to the effect that trafficked people should in fact be viewed as victims of crime (a point advanced by the UN in the TOC and its attendant protocols) traffickers themselves are deemed to have indoctrinated their victims into fearing law enforcement intervention rather than soliciting or embracing it. Aside from this fact, it is well recognised that victims fear for their themselves and/or their families if they testify against their traffickers. Thus, direct retribution against the victim or indirect retribution against their families in addition to the likelihood of being retrafficked should they be returned to their home country serve as powerful disincentives to engage in the criminal justice process.

Trafficking in persons, whether for sexual or labour exploitation (it is a common mistake to suppose that trafficking relates only to the sex industry when in actuality, children are trafficked to work in sweatshops as bonded labour and men work in what the UNODC terms '3D jobs', i.e. dirty, difficult and dangerous), remains, despite the increasing focus being placed upon it by governments and their law enforcement agencies, a relatively high value and low risk enterprise. The methodology of traffickers is simply to prey upon the vulnerable, usually children and young women. Their ploys are creative and designed to trick, coerce and win the confidence of potential victims. These ploys may include promises of marriage, employment or educational opportunities. In West Africa a trader may persuade a child's parents that he will train the boy or girl in a valuable vocation in the country's big city. Once outside of the village, the trafficker will then sell the boys to a gang sending children to a neighbouring country for work in a rock quarry. Girls will be sent to a brothel in the capital. In Northern Uganda, rebels from the Lord's Resistance Army are reputed to abduct young children form villages to serve as soldiers and sex slaves. In rural areas of Latin America, traffickers prey on 
vulnerable teenage girls who want to move to large cities and promises of employment then mutates into prostitution. In the aftermath of the 2004 tsunami in the Indian Ocean there were reports of rape, sexual abuse, kidnapping and trafficking in persons in the countries affected by it.

Schloenhardt (1999) maintains that trafficking organisations vary considerably in size and involvement in the trade. He discerns three key variants.

1. amateur - often individuals who provide a single service such as the transport for the trafficking of persons across a border;

2. small organised crime groups - groups which facilitate the movement of groups of trafficked persons from one country to another; and

3. transnational trafficking networks - large enterprises that manage the trafficking process from recruitment to 'employment' within a destination country.

Williams (2001) argues that transnational crime networks provide criminals with access to people with specific resources, which create mutually advantageous information benefits and exchange relationships. Logically, there must be a high degree of organisation involved. It is no easy task to take groups of people on a frequent basis through a number of countries without being discovered or compromised. It also follows, perhaps, that corruption of appropriate parties at appropriate levels must form part of that organisation. People, unlike any other illicit 'commodity', are difficult to conceal. Thus, a transnational trafficking network might reasonably be constituted by a range of dedicated personnel who, collectively, ensure the recruitment, transportation, relocation and exploitation of victims and in consequence provides support to, and assists in the facilitation of, the trafficking process.

The UN regional profile for the Asia-Pacific, for example, illustrates the nature and extent of trafficking in just one geographical region.

\begin{tabular}{|c|c|c|c|c|}
\hline Country & $\begin{array}{l}\text { Source/Transit/ } \\
\text { Destination }\end{array}$ & $\begin{array}{l}\text { Trafficking } \\
\text { Typology }\end{array}$ & $\begin{array}{l}\text { Trafficking } \\
\text { From }\end{array}$ & $\begin{array}{l}\text { Trafficking } \\
\text { To }\end{array}$ \\
\hline China & $\begin{array}{ll}\text { Source } & \& \\
\text { Destination } & \end{array}$ & $\begin{array}{l}\text { Domestic } \\
\text { (kidnapping), } \\
\text { Commercial } \\
\text { Sexual } \\
\text { Exploitation } \\
\text { (CSE), } \\
\text { marriage, forced } \\
\text { labour, } \\
\text { adoption, child } \\
\text { sex }\end{array}$ & China & $\begin{array}{l}\text { Hong Kong, } \\
\text { Macau, } \\
\text { Malaysia, } \\
\text { Japan, } \\
\text { Singapore, } \\
\text { Indonesia, US, } \\
\text { UK, Australia, } \\
\text { Burma, } \\
\text { Cambodia and } \\
\text { Thailand }\end{array}$ \\
\hline Thailand & $\begin{array}{l}\text { Source, Transit } \\
\text { and Destination }\end{array}$ & $\begin{array}{l}\text { CSE, forced } \\
\text { labour }\end{array}$ & Thailand & $\begin{array}{l}\text { US, UK, } \\
\text { Australia, } \\
\text { Hong Kong, }\end{array}$ \\
\hline
\end{tabular}




\begin{tabular}{|c|c|c|c|c|}
\hline & & & & $\begin{array}{l}\text { Macau, Japan } \\
\text { and Taiwan }\end{array}$ \\
\hline Myanmar & Source & $\begin{array}{l}\text { CSE, forced } \\
\text { labour, military } \\
\text { conscription, } \\
\text { domestic } \\
\text { (kidnapping) }\end{array}$ & Myanmar & $\begin{array}{l}\text { Thailand, } \\
\text { China, Taiwan, } \\
\text { Pakistan and } \\
\text { Japan }\end{array}$ \\
\hline Vietnam & Source & $\begin{array}{l}\text { Domestic } \\
\text { (kidnapping), } \\
\text { child begging, } \\
\text { CSE, marriage }\end{array}$ & Vietnam & $\begin{array}{l}\text { China, Taiwan, } \\
\text { Japan, } \\
\text { Cambodia and } \\
\text { Thailand }\end{array}$ \\
\hline Lao & Source & $\begin{array}{l}\text { CSE, forced } \\
\text { labour }\end{array}$ & Lao & $\begin{array}{l}\text { China, } \\
\text { Thailand and } \\
\text { Cambodia }\end{array}$ \\
\hline Cambodia & Source & $\begin{array}{l}\text { Domestic } \\
\text { (kidnapping), } \\
\text { CSE, forced } \\
\text { labour, begging }\end{array}$ & Cambodia & $\begin{array}{l}\text { Thailand and } \\
\text { Vietnam }\end{array}$ \\
\hline Japan & Destination & CSE, child sex & $\begin{array}{l}\text { China, Taiwan, } \\
\text { Vietnam, } \\
\text { Central Asia, } \\
\text { Russia, South } \\
\text { Korea, } \\
\text { Cambodia and } \\
\text { the Philippines }\end{array}$ & Japan \\
\hline Taiwan & Destination & CSE, marriage & $\begin{array}{l}\text { China, } \\
\text { Vietnam, } \\
\text { Central Asia, } \\
\text { Russia, South } \\
\text { Korea, } \\
\text { Cambodia and } \\
\text { the Philippines }\end{array}$ & Taiwan \\
\hline $\begin{array}{l}\text { South } \\
\text { Korea }\end{array}$ & $\begin{array}{l}\text { Source, Transit } \\
\text { and Destination }\end{array}$ & CSE & $\begin{array}{l}\text { China, } \\
\text { Vietnam, } \\
\text { Thailand, } \\
\text { Central Asia } \\
\text { and Russia } \\
\end{array}$ & South Korea \\
\hline $\begin{array}{l}\text { Hong } \\
\text { Kong }\end{array}$ & $\begin{array}{l}\text { Destination and } \\
\text { Transit }\end{array}$ & $\mathrm{CSE}$ & $\begin{array}{l}\text { China, } \\
\text { Thailand, } \\
\text { Central Asia, } \\
\text { Russia, } \\
\text { Vietnam and } \\
\text { the Philippines }\end{array}$ & Hong Kong \\
\hline Macau & Destination & CSE & $\begin{array}{l}\text { Thailand, } \\
\text { Vietnam, } \\
\text { China, Central } \\
\text { Asia and } \\
\text { Russia } \\
\end{array}$ & Macau \\
\hline Malaysia & Destination & $\begin{array}{l}\text { CSE and forced } \\
\text { labour }\end{array}$ & $\begin{array}{l}\text { Central Asia, } \\
\text { Russia, }\end{array}$ & Malaysia \\
\hline
\end{tabular}




\begin{tabular}{|c|c|c|c|c|}
\hline & & & $\begin{array}{l}\text { Indonesia, } \\
\text { Thailand, } \\
\text { Taiwan, South } \\
\text { Asia, the } \\
\text { Philippines, } \\
\text { Cambodia, } \\
\text { Myanmar and } \\
\text { China }\end{array}$ & \\
\hline Singapore & Destination & CSE & $\begin{array}{l}\text { Malaysia, } \\
\text { China, } \\
\text { Thailand, } \\
\text { South Asia, the } \\
\text { Philippines, } \\
\text { Central Asia } \\
\text { and Russia }\end{array}$ & Singapore \\
\hline $\begin{array}{l}\text { The } \\
\text { Philippines }\end{array}$ & $\begin{array}{l}\text { Source, Transit } \\
\text { and Destination }\end{array}$ & $\begin{array}{l}\text { Domestic } \\
\text { (kidnapping), } \\
\text { CSE and forced } \\
\text { labour }\end{array}$ & $\begin{array}{l}\text { Singapore, } \\
\text { Hong Kong, } \\
\text { Malaysia, } \\
\text { Thailand, } \\
\text { Macau, } \\
\text { Australia, US, } \\
\text { UK and the } \\
\text { Middle East }\end{array}$ & The Philippines \\
\hline Australia & Destination & CSE & $\begin{array}{l}\text { Indonesia, } \\
\text { Malaysia, } \\
\text { Thailand, } \\
\text { Vietnam, } \\
\text { China, Hong } \\
\text { Kong, Taiwan } \\
\text { and } \\
\text { Philippines the } \\
\end{array}$ & Australia \\
\hline $\begin{array}{l}\text { Central } \\
\text { Asia and } \\
\text { Russia }\end{array}$ & Destination & CSE & $\begin{array}{l}\text { Central Asia } \\
\text { and Russia }\end{array}$ & $\begin{array}{l}\text { Thailand, } \\
\text { Malaysia, } \\
\text { Hong Kong } \\
\text { and Macau }\end{array}$ \\
\hline
\end{tabular}

Source: Table created from material within the document 'Human Trafficking: Regional Profile 200303-11', www.unodc.un.or.th/material/document/Regional Profile.pdf

The impact and intricacies of the trafficking phenomenon may be seen in the context of the Philippines. President Gloria Macapagal-Arroyo is the first Philippine head of state to admit that the Philippine economy is not yet ready to absorb the millions of Filipinos working overseas and that they should continue to work abroad. Indeed the number of Filipinos working abroad as contract workers and as immigrants has now reached 10 percent of the entire Philippine population. The Philippines is primarily a source and transit country for trafficking in persons. Internal trafficking is also a problem. The Philippines relies heavily on the repatriated salaries of overseas workers, the majority of whom are women. The constant flow of workers out of the country leaves women vulnerable to the vagaries of traffickers. This risk is exacerbated by the 
fact that over $80 \%$ of the women who travel to work in Japan go as entertainers, a primary channel of prostitution in Asia. Women who travel to work as domestic servants in the Middle East sometimes find themselves in exploitative situations.

The most serious trafficking problem appeared to be the trafficking of Filipina women across international borders to destinations in Asia, Europe, the Middle East and North America. Many of these women were forced to work in the sex industry. A significant percentage of the victims of internal trafficking were from Mindanao and were fleeing the severe poverty and violence of their home areas. The concept that a person has been trafficked person and is a victim rather than a perpetrator has been widely accepted in the Philippines public. Organised crime groups typically traffic persons from China through the country to destinations elsewhere, although occasionally the Philippines is the final destination.

There are approximately 7.4 million Overseas Filipino Workers (OFWs) living and working all over the world. It is estimated that 1.62 million of them are irregular migrants and many of those are suspected of being victims of trafficking. Equally, however, the Philippines rely heavily on the remittances of these workers. In addition to the Philippines Government contacts in other countries, there are numerous national nongovernmental organizations (NGOs) that work to prevent the trafficking of people to other countries, as well as internal child trafficking from one island to another. Many of these NGOs work with other international organizations.

The sexual exploitation of children in the Philippines through pornography, the Internet, and sex tourism is a growing concern. Vilches (2004) has argued that young girls and women in the Philippines are culturally discriminated against in the sense that they are deemed to be sex objects and stereotypically imbued with the role of carer and domestic servant. Vilches (2004) notes that ' $[\mathrm{t}] \mathrm{he}$ pejorative expectations that Filipino society has on women and children are compounded by problems of extreme poverty; massive labour export; globalization; porous borders; aggressive tourism campaigns; negative portrayal of women by mass media; pornography on-line and internet chatrooms; the practice of mail-order brides; inter-country adoption; and joint military exercises in the country with visiting forces from abroad. These factors cause women to become easy victims of sex-trafficking and other forms of sexual exploitation either in the Philippines or in countries of destination.'

As at January 2004, more than 4 million Filipinos were unemployed and $40 \%$ of those were women. There were approximately 600,000 prostitutes in the Philippines in 2000 and 50,000 of those were children. The Philippines is a major source of people trafficked to countries with highly developed and stable economies. In Europe, it is argued that undocumented Filipinos are victims of trafficking perpetrated by Philippine based organised crime groups that have contacts with similar organisations in the destination countries. 
One of the foremost trafficking organisers in the Philippines is the Zabate Group. The group's modus operandi, based on victims' interviews, began with a promise by their recruiters of jobs in Brunei as restaurant workers but resulted in their engagement as prostitutes in Malaysia. The victims were placed on fishing vessels in going to Malaysia whilst those with passports were placed on planes. Upon arrival in Malaysia they were all taken to prostitution dens. Their passports were then collected by the manager of the 'night-club' they were placed in. The passports are believed to be replaced with a photograph of the new user. It is difficult to contain this phenomenon because of the large numbers of documented Overseas Filipino Workers (OFWs) being deployed to developed countries.

The top regions of destination of undocumented Filipinos are America, South and East Asia, the Pacific, Europe, the Middle East and Africa. The top ten countries of destination in chronological order are the United States, Singapore, Canada, Japan, Italy, the United Kingdom, Jordan, Malaysia, South Korea and Saudi Arabia.

Traffickers utilise a range of recruitment methods. These include mail-order brides and adoption. With the former, foreigners who are either married to Filipinos or who have contacts in the Philippines perpetrate this scheme. A contact in the Philippines would recruit beautiful young women and their photographs mailed to or placed on the internet for, potential husbands in developed nations. Some brides recruited in this way may experience a happy marriage but many others are believed to have been treated as sex slaves by their husbands or sold into prostitution.

With the latter, children from the Philippines are smuggled out of the country by foreigners who pretend to adopt them but in actuality place them into child labour markets or sell them into prostitution.

The Philippines Anti-Trafficking in Persons Act 2003 seeks to eliminate trafficking, establish the institutional mechanisms necessary for the protection and support of victims and provide penalties for violations of the law. Trafficking under the new law is interpreted in its broadest sense in that it refers to recruitment, transportation, transfer or harbouring, or receipt of persons with or without the victims' consent or knowledge, within or across national borders by means of threat or use of force or other forms of coercion, abduction, fraud, deception, abuse of power or of position, taking advantage of the vulnerability of the person.

Trafficking also means the giving or receiving of payments or benefits to achieve the consent of a person having control over another person for the purposes of exploitation which includes the exploitation or the prostitution of 
others or other forms of sexual exploitation, forced labour or services, slavery, servitude or the removal or sale of organs.

Generally speaking, a prospective migrant may seek to exit or enter a country legally or illegally. There are many possible combinations, and these may be further complicated by the involvement of organised crime groups. Beare (1999) has categorised the possible combinations, which are not mutually exclusive, as follows:

- Legal - legal: the migrant applies for immigrant status, gains legal entry and remains in the country as a legal migrant.

- Illegal - legal: this may include those migrants who enter a country illegally, using false documents or evading immigration restrictions, and who seek to change their status after arrival.

- Legal - illegal: this group is said to comprise the largest percentage of the 'illegal' migrant population. These migrants enter the country legally with time-specific visas and then fail to return to their countries of origin.

- Illegal - illegal (independent): this group enters the country illegally and remains illegal but without the assistance of organised criminal groups;

- Illegal - illegal (indentured): this category is perhaps the most vulnerable, in that they are undocumented, and also at the mercy of the criminals who assisted their passage and employment. These migrants have incurred large debts for their passage and these may take long periods of time to repay.

- Legal - legal (indentured): legal entry into a country does not ensure easy entry - and legal entry does not immunise one from being under the control of those people who helped to finance the arrival. Legal status may improve job prospects, however, the amount of money to pay back may still mean that crime is a necessary or attractive option.

Migration from the Philippines can be categorised along similar lines, as organised crime groups have been known to intervene at one or more of the various stages of the migration process. Strict regulations in the Philippines limit labour migration abroad. If a Filipino does not have a valid passport, they could seek to exit the country through the 'escort system', that is, they can pay a bribe to an airport or immigration official and by-pass immigration controls. Organised crime groups may be involved in these processes. Alternatively, a migrant could travel through the 'Southern back-door', an area of the Philippines that is subject to minimal official surveillance and is physically close to Malaysia. The Southern Back Door is considered a sizeable problem and a number of disparate routes from this point are utilised. As a result of consultations between the Philippine and Malaysian governments, Border Crossing Stations between the two countries have recently been opened. The successful operation of these Stations is, however, currently limited by a lack of resources. 
With respect to entry to the destination country, migrants can use legal channels, such as legitimate work permits, tourist visas, or if the destination country is a member of ASEAN, there is no requirement for the Filipino migrant to have a visa if their intended stay is less than 30 days. Some Filipino workers use the ASEAN countries as a jump-off point for further migration to third countries. Cyprus and the former Yugoslavia have also been identified as major transit points for the transport of migrants to the USA and Western Europe. Once in the destination country, Filipino workers who were otherwise in the country legally may become undocumented, either because of overstay, or through taking up employment in contravention of their tourist visa.

The prospect of traffickers being detected, if detected prosecuted and if sentenced subject to a significant term of imprisonment remains low. This is exacerbated by evidential issues (whereby the victims are naturally reluctant to testify) and the vagaries created by often systematic corruption with law enforcement agencies and the judiciary in some nation states.

Indeed, trafficking in persons, whether sophisticated or elementary in nature, necessitates the crossing of geographical borders and arguably transnational crime networks could not achieve the movement of victims without the active or passive collusion of corrupt politicians, judiciary, law enforcement and other officials. It is they who facilitate the trafficking process through a myriad of ways ranging from the provision of fraudulent documents to the formulation of decisions either not to prosecute apprehended traffickers or to impose disproportionately low sentences upon the few who are brought before the courts. As the profits generated by trafficking, and the demand for trafficked persons, increase, the need for further and intensified corruption will also continue to rise. If trafficking is to be mitigated, the symbiotic relationship that exists between corrupted officials and transnational criminal networks must be systematically addressed. As Williams (2004) observes, '[w]hile the official is not part of the criminal enterprise he has become a vital node in a criminal network providing important services including timely intelligence about law enforcement initiatives'.

It is arguable that at some point the increased risk that increased activity on the part of the transnational crime group renders its relationship with its corruptees from one of symbiosis to one of parasitism. Certainly, transnational crime networks must increase the range and volume of their corruption network in order to obtain protection and information. Trafficking is often portrayed as a low-risk/high profit activity. Risk and profit are of course relative concepts. If, for example, intelligence is not secured through corruption, the risk rises and the prospective profits fall. If the relevant border officials or local government officers have not been bribed and are not able in consequence to provide the required documentation for the trafficked victims, those victims suddenly become highly visible and the risk once again rises and the profit margin falls. 
The Programme against Corruption and Organised Crime in South-eastern Europe (PACO 2002) has suggested that opportunities for corruption exist at a number of stages in the trafficking process, namely the trafficking chain, the criminal justice chain and the victim chain.

\section{Trafficking chain}

The recruitment or acquisition of victims, provision of documentation (identification papers, visas and permits, etc), transportation within country or across its borders, continued control and exploitation of victims and the laundering of illicit proceeds arguably necessitate and facilitate corruptive practices. The conduits through which such practices might flow may include police and customs officers, embassy staff, border control officers, immigration services, local officials, intelligence and security services, armed forces, elements from the private sector (travel agencies, airlines, transportation sector, financial institutions and banks) and people of influence.

\section{Criminal justice chain}

Proactive or reactive measures undertaken by relevant personnel may enhance the likelihood of a trafficker not being arrested, or if arrested not being prosecuted, or if prosecuted not being incarcerated. The failure to draft or adopt pertinent legislation, haphazard investigations into specific offences, incomplete or spurious search and seizure of illicit proceeds, ineffectual or tainted prosecution, trial and verdicts, and poor enforcement of sanctions may all contribute to the protection of the trafficker.

\section{Victim chain}

Corruption and organised crime elements might be present among NGOs and public social service institutions, which ostensibly provide support, protection and shelter to victims. Infiltrated organisations such as these may in consequence harbour corrupt individuals willing to reveal information concerning the location of victims to traffickers.

PACO suggests that in one study of European countries, the police departments seemed to be a focal point of trafficking. Thus, police departments in charge of registering foreign citizens were believed to accept bribes to issue work and residence permits for foreign 'dancers'. In addition, local police and political authorities may provide protection to pubs and bars in exchange for money or sexual services and may collaborate with pimps to put victims who were arrested or under protection back on the streets to be re-trafficked or prevented from testifying.

The US Trafficking in Persons (TIP) Report (US State Department 2004) revealed a number of countries for which there appears to be evidence of 
corruption and many more in which corruption is perceived to exist. In the East Asia-Pacific region, for example, Burma noted a major corruption problem in the form of local and regional officials suspected of complicity in trafficking and reports that the Burmese military continues to carry out trafficking abuses including forced portering and forced labour. Cambodia is deemed to have a weak judiciary with anti-trafficking efforts hampered by endemic corruption and an ineffectual judicial system. Cambodian government officials and their families are believed to be involved in or to profit from trafficking activities. The Indonesian Government has dismissed civilian and police officials involved in producing false identification and the Vietnamese Government prosecuted three police officers in 2003 responsible for facilitating labour trafficking.

In other regions, the level and range of corruption continues unabated. In South Africa in 2003, six immigration officials, five police officers and airport inspection officers were arrested for facilitating illegal immigration into South Africa. In Azerbaijan, the government dismissed the chief of a regional passport registration office and two inspectors for issuing illegal citizenship identification cards to several individuals. In Bosnia and Herzegovina in 2004, federal authorities arrested the local Interpol Deputy Director on corruption charges and in the Kyrgyzstan 2004 police arrested three people involved in a trafficking scheme including an immigration official and a former employee of the state passport department.

The revelations of the TIP Report point to at least two points of linked concern. First, the fact that there are any cases of corruption in relation to trafficking is disturbing. Secondly, and more importantly, however, the fact that more cases have not been identified suggests, if anecdotal evidence alone on the nature and extent of corruption is to be believed, that there has been a lack of concerted action taken and attention paid to the presence and role of corruption in the facilitation of trafficking.

The crime-corruption nexus will continue to spiral given that transnational crime feeds corruption and that, in turn, corruption nourishes transnational crime. To reduce corruption there remains a need to reduce transnational crime per se, not simply transnational crime in relation to trafficking in people. At the local level, there remains a need to remove the cultural rationalisation of corruption whilst at the same time removing the endemic nature of corruption. Aside from sweeping changes in global societal values, such momentous changes will only be facilitated by a suitable macro-economic consensus in relation to world economic differences. What is certain is that attempting to tackle trafficking without simultaneously attempting to tackle the corruption that facilitates it is to court disaster.

The quantitative nature of trafficking in persons remains an enigma. The latest US Department of State Trafficking in Persons Report (US Department of State 
2005) maintains that between $600,000-800,000$ men, women and children are trafficked annually with approximately 80 percent being woman and girls, up to 50 percent being minors and most trafficked for the purposes of commercial sexual exploitation. Discerning accurate figures, however, is notoriously difficult to achieve. There is clearly an abundance of quantitative and qualitative data on the nature, volume and extent of human trafficking. What there is not, however, is a universal faith in the reliability and verifiability of that data. Governments creating policy in the area of human trafficking, at both the national and international levels, must be able to quantify, as far as the characteristics of human trafficking permit, the true extent of the problem. Only then can governments apportion that part of their budgets that both meets the demands of the problem and more importantly directs funds to where they are most needed. There is no doubt that trafficking is a growing and lucrative market but the size and manifestations of that market remain to be adequately documented. From a pragmatic perspective, law enforcement agencies cannot readily commit their allocated resources to the issue of trafficking unless they can establish from reliable data that their actions and interventions will actually resonate on the ground.

Governments seek increasingly to create policy centered around a sound evidence base. Solesbury (2001) maintains that in order to do so, three key questions must be posed:

- How relevant is the evidence being examined to the issue at hand?

- How representative is the evidence of the group being studied?

- How reliable, theoretically and empirically, is the evidence?

It seems essential that these questions be applied to the issue of human trafficking by all of those involved in countering it at whatever level. Collections of data which cannot satisfy issues of relevancy, representativeness and reliability should not be made available nor utilised.

Davies and Nutley (2002) argue, in relation to research-based knowledge per $s e$, that there are large gaps and ambiguities and that research literature is replete with small, ad hoc studies, varying in approach and of questionable methodological quality. The consequence is that there is little prospect of a reliable knowledge base being created upon which policy makers can securely draw. This, arguably, could effectively describe the current situation facing policy makers in the area of human trafficking.

Broadly speaking, research in connection with human trafficking thus far has tended to focus upon:

- Estimating the scale of the problem;

- Identifying trafficking routes and the relationships that exist between countries of origin, transit and destination. 
- Documenting methods of recruitment

Determining the nature and impact of control mechanisms used by traffickers and the subsequent human rights abuses involved and

- Critically reviewing the nature of the current legal and policy frameworks and recommending new approaches.

It seems, however, that few studies have attempted to obtain, or succeeded in obtaining, data on each of the aforementioned fields within the same program of research during a specific period. Arguably, tackling human trafficking requires a holistic approach which incorporates all of the aforementioned variables. Equally, the data tends to focus upon the sexual exploitation of women and children within prostitution. It does not routinely include other forms of sexual exploitation such as pornography, live sex shows, peep shows, stripping or lap dancing. Nor does the data focus on other forms of exploitation such as forced labour within the domestic, agricultural or industrial context. Interestingly, little focus is placed upon the trafficking of men and boys for some or all of the aforementioned purposes.

There is undoubtedly a large swathe of such evidence collected, collated and disseminated by a multiplicity of NGOs and government agencies. Bertone (2004) argues, however, that "...transnational NGO activity shows that no coherent strategy exits to address trafficking in females for sexual exploitation simply because it is such a complex issue." She notes that there has been a proliferation of organisations all over the world which are engaged in studying trafficking, creating trafficking programs and advocating against it. She argues that a consequence of the sheer volume and differing motivations and ideals of each of those groups is "...a particular personality of extreme politicisation from the local to global levels, and many organizations are vying for limited resources to combat trafficking."

Arguably, many NGOs are victims of their own dedication and enthusiasm. Each fervently believes in the necessity of their role and in their ability to achieve meaningful outcomes in the fight against human trafficking. When data is collected however and that data is subsequently used to influence government policy or public opinion that dedication may influence the ability of the NGO to create a reliable, accurate and objective research base. It seems likely that data is collected largely or solely in relation to those they encounter within the remit of their organisation's operational purpose. Within that context, data collected may relate to a specific program being undertaken by the NGO. Data will usually be drawn from interviews with victims, but anecdotal evidence is not sufficient to guide, inform and justify major policy initiatives. Data may be based upon an agency, rather than a globally understood and accepted, definition of trafficking. The size, scope and quality of the data may be affected by the size, scope and quality of the NGO, whether in political, cultural or financial terms. There may be a political motivation behind the collection or interpretation of data. All such factors impact upon the 
eventual quality of the data. Given the crucial role played by NGOs and given the privileged access NGOs have to victims of trafficking their continued role in effectively conveying the experiences of such victims cannot be underestimated. This makes it all the more important that their data is collected in a systematic and organised manner.

Problems inherent in the data are numerous. Establishing the scale of trafficking has become the essential research output but it is not certain whether the data collected is of the type actually required by governments and law enforcement agencies to prosecute a campaign against human trafficking. Were research to focus equally, if not more so, upon a systematic and detailed analysis of trafficking trends and motivations the relevant bodies might be in a better position to make significant advances in their campaigns against the trafficking phenomenon.

A key impediment to any successful and meaningful collection of data lies in the failure on the part of some to distinguish between 'trafficking' and 'smuggling'. The characteristics of each in terms of organisation, nature and human and financial costs demand that their evaluation for data-collecting purposes remains equally distinct.

To effectively collect data on trafficking in human beings, the term 'trafficking' must be clearly defined, and the best current guidance is probably that contained in the UN Protocol to Prevent, Suppress and Punish Trafficking in Persons, Especially Women and Children (UN 2000). This provides (Article 3, subparagraph (a)) that "'trafficking in persons" shall mean the recruitment, transportation, transfer, harbouring or receipt of persons, by means of the threat or use of force or other forms of coercion, of abduction, of fraud, of deception, of the abuse of power or of a position of vulnerability or of the giving or receiving of payments or benefits to achieve the consent of a person having control over another person, for the purpose of exploitation. Exploitation shall include, at a minimum, the exploitation of the prostitution of others or other forms of sexual exploitation, forced labour or services, slavery or practices similar to slavery, servitude or the removal of organs.'

However, this definition, as with many definitions in international treaties and legislation, has been left intentionally wide so as to encapsulate as many offenders/offences and variations in national legal approaches as possible. The negative impact of this feature, however, lies in the fact that trafficking may entail a range of criminal activities and involvement across a number of countries. The ability, or commitment, of authorities within those jurisdictions to prosecute offenders may differ within and between territories.

It is certainly the case that many governments have not yet created a universal method of data collection and it is common for many countries to mix data on 
trafficking, smuggling and irregular migration. Doing so renders the obtaining of essential trafficking data more problematic still.

Even where data is collected, very few countries are able to provide data on trends in trafficking over a period of years, and this makes it difficult to establish the extent to which trafficking might be increasing or decreasing in response to, or as a result of the lack of, applicable legislation. Trafficking often involves organised crime groups and even without their presence the trade remains largely secretive and is buoyed up through a mixture of violence and corruption. In consequence, trafficking remains an essentially unreported or underreported crime in which the majority of perpetrators escape arrest and prosecution and the majority of victims remain undiscovered.

Much of the available data on the extent and nature of the trafficking process is obtained from intercepted victims. The knowledge possessed by those victims, however, will invariably be limited to their own immediate experience. They will not have a detailed knowledge of the entire trafficking operation but merely those parts of it which involved them directly, for example, where they originated from, how they travelled, how much they were charged and where they eventually worked. It is tempting perhaps to extrapolate from the experiences of one that such is the norm for all previous and subsequent victims. It seems unlikely, however, that traffickers would fall into such a malaise especially as the testimony of one escapee could undermine (albeit temporarily) the entire operation. The context in which victims are interviewed may have a subtle bearing on what they say. Thus, one might expect different responses from a victim interviewed at a border detention centre as opposed to one interviewed within a structured return program.

Low priority may be given to the investigation of trafficking in many countries because (a) legislation is often lacking, inadequate or not implemented which makes prosecution difficult and (b) convictions are often based on witness and or victim testimony. Such testimony is often difficult to obtain because the victim may be unwilling to reveal information if their own safety and that of their families cannot be guaranteed.

The other key issue in relation to data is the extent to which it is, or more appropriately, is not shared with other relevant agencies. There seems to be a general reluctance on the part of some agencies within countries and between countries to share trafficking-related data. Sharing of data is often done on an ad hoc basis because such data may be classified. Some agencies may simply be embarrassed about the quality or quantity of their data. Some destination agencies may be concerned that the police or government sources they reveal information to could be involved directly or indirectly with trafficking. Some NGOs may not wish to share data because of the undertakings of confidentiality they provided in order to obtain the data in the first instance. 
The International Organisation for Migration (IOM) collects first-hand information from IOM field missions working on counter-trafficking as part of its Counter Trafficking Module (CTM) Database. It carries out in-depth interviews based on a standard questionnaire with all trafficked persons who receive IOM assistance. Information gathered includes the victims' socioeconomic background, manner and means used for their recruitment, route taken, their experience and any other relevant information including their health and welfare needs. This is fed into a database and provides assistance in identifying patterns and mechanisms of trafficking. However, it only deals with those who seek the assistance of the IOM and not necessarily all those who have been trafficked.

The United Nations Global Programme against Trafficking in Human Beings established a database to attempt to bring some semblance of authority and order to the vast range of source material on the issue. The database was designed to incorporate open source material dealing with all pertinent issues relating to trafficking. Such sources include official government reports, intergovernmental and non-governmental organisations, research reports, conference publications and media reports. However, issues remain as to the weight attached to certain sources and of the consequences of that weighting in relation to determinations that a particular country is one of origin, transit and/or destination. One might question, however, why information in which there is not total confidence should be included in the database. There is perhaps a danger that the sheer volume of information of varying quality and reliability logged on the database will continue to fuel the uncertainty that already exists around trafficking data. Filtering information with a view to removing that upon which there is some doubt should be an integral part of the process. This is especially important when one considers the fact that a key motivation behind the database was to increase the comparability of data between countries and regions.

The key question to pose in relation to the collection, analysis and dissemination of data is whether the data produced actually assist in the fight against trafficking. Does knowledge of global trafficking rates, for example, actually assist in terms of policy development and delivery or in terms of pragmatic action, save for confirming that it is a large and growing problem? There are no global figures, for example, for other serious crimes such as homicide or rape despite the very clear evidence at the national level that in many countries such crimes are rife. Is this because such crimes are largely confined within national borders or because the possession of global figures concerning their extent would not actually advance the fight against them?

Arguably, where human trafficking differs from other serious crimes is in its transnational manifestations and in the numerous ancillary activities which facilitate it. Having only sound data for a country or region to the exclusion of all other countries or regions is a serious impediment to the successful 
mitigation or eradication of a phenomenon that routinely transcends national and international borders.

It seems logical to obtain data which is actually needed rather than to continue to accept data which happens to be collected and collated. Thus, governments, NGOs and law enforcement agencies need to establish what information they require in order to begin to tackle trafficking. If, for example, an understanding of the methods of recruiting is central to an anti-trafficking approach, then data on that issue should be collected and collated.

Indeed, a more useful and possibly more readily attainable approach might be to concentrate instead on the essential characteristics of the trafficking process rather than to doggedly pursue the holy grail of victim quantification. Whatever the chosen course of action, there must be a clear stipulation as to the rationale for collecting particular data and a concentration upon how this can best be achieved.

All countries in which trafficking is an issue may have a number of governmental and non-governmental bodies collecting data from a range of disparate sources for a number of different reasons. It is imperative that such data should be collated and analysed by one agency in pursuance of agreed research targets in relation to human trafficking.

There should be an equal if not greater focus upon indirect indicators of human trafficking which might include, for example, the number of entertainment visas issued for those working in the entertainment business (anecdotally a destination for trafficked persons). Other indicators might include the number, gender and origin of asylum seekers, figures on the number of illegal border crossings, statistics on departures of women leaving main countries of origin, the demand for visas at foreign consulates for the main countries of transit and destination. Data sharing at a national level must occur routinely if there is to be any realistic prospect of consistent data sharing at the regional and international levels.

Although it may seem self-evident, the importance of collecting effective data should continue to be stressed. Universally applied indicators of trafficking should be incorporated into every collection of data. Victims should be interviewed in relation to specific questions which feed directly into the data collection. Effective methodologies for the effective collection of data by relevant law enforcement, government departments and NGOs should be established and adhered to and any data obtained outside those detailed parameters should be ignored. Data on the full scope of trafficking should be collected for men, women and children within sex-based and non sex-based industries. The patterns of domestic trafficking should be examined in terms of their relationship (if any) with transnational trafficking and a systematic 
attempt made to understand fully the structures and methodologies of trafficking organisations and their links to corrupt governments and officials.

\section{References}

Beare, M 1999. 'Illegal Migration' in C. Hernandez and G. Pattugalan (eds), Transnational Crime and Regional Security in the Asia Pacific, Council for Security Cooperation in the Asia Pacific, Institute for Strategic and Development Studies, Philippines.

Bertone, A. M. 2004. 'Transnational Activism to Combat Trafficking in Persons', Brown Journal of World Affairs, Spring 2004, Vol. X, Issue 2.

Davies, H and Nutley, S 2002. 'Evidence-based Policy and Practice: Moving from Rhetoric to Reality', Discussion Paper 2, Research Unit for Research Utilisation, University of St Andrews.

IOM (International Organization for Migration) 2005. Fertile Fields: Trafficking in Persons in Central Asia.

PACO (Programme against Corruption and Organised Crime in South-eastern Europe), Trafficking in Human Beings and Corruption.

Piotrowicz, R 2004. 'European Initiatives in the Protection of Victims of Trafficking who Give Evidence Against Their Traffickers', International Journal of Refugee Law, Vol.14 No. 2/3.

Schloenhardt, A 1999. 'Organised Crime and the Business of Migrant Smuggling: An Economic Analysis’, Crime, Law \& Social Change, Vol. 32.

Solesbury, W 2001. 'Evidence Based Policy: Whence it Came and Where It's Going', Working Paper 1, ESRC UK Centre for Evidence Based Policy and Practice.

UN 2000. Protocol to Prevent, Suppress and Punish Trafficking in Persons, Especially Women and Children, http://www.uncjin.org/Documents/Conventions/dcatoc/final_documents_2/con vention_\%20traff_eng.pdf

UNODC (United Nations Office on Drugs and Crime) 2003. Human Trafficking: Regional Profile 2003-03-11.

US Department of State 2004. Trafficking in Persons Report 2004.

US Department of State 2005. Trafficking in Persons Report 2005. 
Vilches, N.C. 2004. Trafficking of Women and Children, http://www.expertlaw.com/library/domestic_violence/Philippines_trafficking.h tml

Williams, P 2001. 'Organizing Transnational Crime: Networks, Markets and Hierarchies' in P. Williams and D. Vlassis (eds) 2001, Combating

Transnational Crime: Concepts, Activities and Responses, Frank Cass, London.

Williams, P 2004. 'Transnational Crime Networks' in J. Arquilla and D. Ronfeldt (eds) Networks and Netwars: The Future of Terror, Crime, and Militancy, RAND. 